\title{
PERAN MASYARAKAT DALAM PENGEMBANGAN DESA WISATA BERBASIS MASYARAKAT
}

\author{
Dian Herdiana \\ Sekolah Tinggi Ilmu Administrasi (STIA) Cimahi \\ Email: kyberdian@gmail.com
}

\begin{abstract}
Village tourism is an alternative form of tourism that presents the beauty of nature, social life and culture, it offers direct interaction with the local community as a form of tourist attraction offered. However, in practice, community is not fully involved in the process of village tourism development hence the community is not benefited from the village tourism. On the basis of existing problems, this article is intended to explain the importance of community involvement in village tourism development. This research is a qualitative study using a library research approach. The results show that the village tourism will be going to succeed if the community is being involved in the whole process. The community should be placed into 2 (two) roles at once, namely the community as the subject that has the right to determine the direction of village tourism development. Secondly, the community as an object where the goal of increasing community welfare is a priority in the village tourism development.
\end{abstract}

Keywords: Village Tourism, Community, Empowerment, Development.

\section{Pendahuluan}

Pariwisata tidak hanya menjadi ajang memperkenalkan jati diri sebuah negara kepada dunia, tetapi sudah menjadi sebuah indrustri yang mampu mendorong kemajuan perekonomian. Dalam perkembangannya, pariwisata telah banyak mengalami perluasan dan telah terdiversifikasi dalam berbagai bentuk, sehingga sektor wisata selain berkembang menjadi sektor industri jasa kreatif, juga menjadi sektor ekonomi yang mengalami pertumbuhan paling cepat diantara sektor ekonomi lainnya di dunia (Sukirman, 2017). Secara global diperkirakan pada tahun 2020 akan ada 1.6 miliar jiwa yang akan melakukan kegiatan pariwisata di seluruh 
dunia dengan total valuasi ekonomi mencapai USD 2.000 milliar (Hermantoro dalam Rizkianto dan Topowijono, 2018).

Sejalan dengan perkembangan pariwisata secara global, pariwisata di Indonesia sudah mampu memberikan kontribusi terhadap perekonomian nasional, setidaknya berdasarkan kepada data tahun 2017 tercatat sebesar Rp.172 triliun atau 11,3\% dari PDB Indonesia disumbangkan dari sektor pariwisata (Alamsjah dalam Trianggono dkk, 2018). Dilihat dari bentuk pariwisata, perkembangan pariwisata di Indonesia pada saat ini menunjukan adanya kecenderungan pergeseran bentuk pariwisata dari yang dahulunya kepada pariwisata massal (mass toursm) berubah menjadi kepada pariwisata alternatif (alternative tourism). Hal ini salah satunya dilatarbelakangi adanya perubahan pandangan khususnya pada para wisatawan yang sudah matang, berpengalaman dan berpendidikan (mature market) mengenai akan pentingnya pariwisata yang berbasis kepada konservasi lingkungan dan pemberdayaan masyarakat lokal (Rizkianto dan Topowijono, 2018). Dasar dari alasan tersebut yaitu sebagai bentuk dukungan terhadap pelestarian alam sekaligus sebagai kritik terhadap pariwisata masal yang selama ini dianggap lebih condong kepada mencari keuntungan dibandingkan dengan isu keberlanjutan dan kelestarian lingkungan.

Alternatif pariwisata yang didasarkan kepada pelestarian alam dan pemberdayaan masyarakat lokal salah satu bentuknya adalah desa wisata, dimana proses pengembangan wisata yang dilaksanakan didasarkan kepada penggalian potensi sumber daya yang ada di desa beserta pemberdayaan masyarakat lokal. Atas dasar tersebut, maka pemerintah Indonesia sudah mulai mengintensifkan pengembangan desa wisata sejak satu dasawarsa terakhir guna menjawab kegiatan pariwisata alternatif. Adanya upaya pengembangan desa wisata juga dilatarbelakangi adanya keinginan pemerintah untuk memberdayakan dan 
meningkatkan perekonomian masyarakat desa dimana masih banyak desa yang berstatus desa tertinggal.

Praktek pengembangan desa wisata di Indonesia sudah banyak memunculkan desa wisata di berbagai daerah berdasar kepada potensi desanya masing-masing, setidaknya sampai tahun 2016 sudah ada 576 desa wisata sungai, 165 desa wisata irigasi, 374 desa wisata danau (Rizkianto dan Topowijono, 2018). Jumlah desa wisata tersebut akan terus berkembang sesuai dengan kebijakan pengembangan wisata yang dilakukan oleh pemerintah daerah masing-masing.

Proses pengembangan desa wisata dalam prakteknya menghadapi berbagai permasalahan, secara umum permasalahan yang terjadi yaitu tidak dioptimalkannya peran masyarakat, sehingga masyarakat tidak hanya merasa kurang memiliki rasa bangga terhadap pariwisata yang ada di desanya, tetapi juga masyarakat tidak mendapatkan keuntungan dari adanya kegiatan pariwisata yang ada di desa.

Salah satu contoh dari kurang dilibatkannya masyarakat dalam pengembangan desa wisata yaitu di Desa Wisata Jatiluwih Bali, dimana peran pemerintah masih dominan dan memiliki kencenderungan memihak dan mengutamakan kepentingan investor dalam pengembangan desa wisata (Dewi dkk., 2013). Hal tersebut diatas didukung hasil penelitian oleh Muallisin (2007) yang menyatakan bahwa pengembangan pariwisata di Yogyakarta masih minim partisipasi masyarakat, dikarenakan dalam proses pengembangannya banyak merekrut masyarakat luar dibanding dengan masyarakat lokal itu sendiri.

Di sisi lain, pengembangan desa wisata juga tidak didukung dengan proses pemberdayaan masyarakat, sehingga masyarakat tidak memiliki kapasitas dalam pengembangan desa wisata, hal ini sebagaimana penelitian yang dilakukan oleh Purnamasari (2011) di Kampung Wisata Toddabojo Sulawesi Selatan yang mana 
masyarakat belum mampu secara mandiri mengembangkan desa wisata. Hal tersebut di atas sejalan dengan hasil penelitian yang dilakukan oleh Nawawi (2013) yang mana meskipun keterlibatan masyarakat dalam pariwisata sudah ada dengan didirikannya koperasi, namun dukungan pemerintah masih minim baik itu terhadap pengembangan koperasi seperti pencatatan administrasi dan dokumentasi yang masih minim, maupun bentuk pengelolaan lainnya seperti belum optimalnya pendidikan akan kesadaran lingkungan oleh masyarakat, seperti kurangnya pengelolaan sampah yang baik, penataan pedagang dan lapak warung makan yang belum tertib.

Permasalahan tersebut diatas, hakekatnya merupakan bentuk dari kurang dipahaminya pengembangan desa wisata yang mengakomodir peran masyarakat untuk secara langsung terlibat dalam keseluruhan proses pengembangannnya dan memiliki hak untuk menerima manfaat dari kebijakan pengembangan desa wisata. Atas dasar tersebut, maka artikel ini mencoba menjelaskan bagaimana pentingnya peran masyarakat dalam pengembangan desa wisata berbasis masyarakat.

\section{Landasan Teori dan Konsep}

\section{Pariwisata}

Secara umum wisata dapat diartikan dengan perjalanan atau berpergian, sedangkan pariwisata memiliki tambahan kata yaitu "pari" yang berarti penuh, lengkap, berkeliling atau berkali-kali (Suwantoro, 2001). Para ahli mengemukan berbagai pemahaman mengenai pariwisata, seperti Spillane (1987) yang menyatakan bahwa pariwisata merupakan perjalanan dari suatu tempat ke tempat lainnya yang bersifat sementara, baik dilakukan oleh perorangan maupun secara berkelompok sebagai suatu usaha mencari keseimbangan dan kebahagiaan dengan lingkuangan hidup dalam dimensi sosial, budaya, alam dan ilmu. 
Menurut Wahab (2003) bahwa pariwisata merupakan suatu perpindahan sementara organisasi yang mempunyai pola hidup berbeda. Sedangkan Karyono (1997) membagi definisi pariwisata secara umum dan secara teknis, yaitu pariwisata dalam konteks umum diartikan sebagai keseluruhan kegiatan pemerintah, dunia usaha dan masyarakat untuk mengatur mengurus dan melayani kebutuhan wisatawan, sedangkan secara teknis, pariwisata merupakan suatu rangkaian kegiatan yang dilakukan oleh manusia baik perorangan maupun kelompok di dalam wilayah negara sendiri atau negara lain.

Pemahaman pariwisata dari ahli tersebut di atas pada dasarnya memiliki kesamaan, yaitu: Pertama, pariwisata merupakan aktivitas temporal atau sementara waktu. Kedua, dilakukan baik oleh pribadi/perorangan maupun oleh kelompok. Ketiga, lokasi berada di luar lingkungan tempat tinggalnya. Keempat, bertujuan mencari pengalaman atau sesuatu yang disukai. Kelima, ditunjukkan bukan untuk mencari keuntungan (motif ekonomi).

\section{Perkembangan Bentuk Pariwisata}

Bentuk pariwisata dalam prakteknya telah banyak mengalami perkembangan, sampai saat ini setidaknya terdapat dua arus utama bentuk pariwisata yang dikembangkan di dunia, yaitu bentuk pariwisata massal (mass tourism) dan bentuk pariwisata alternatif (alternative tourism), dimana dalam hal pendekatan konseptual keduanya memiliki karakter yang berbeda (Neil dan Wearing, 1999). Tidak ada definisi yang baku mengenai seperti apa pengertian dan bagaimana konsep pariwisata massal itu (Lindberg, Enriquez, dan Sproule, 1997). Namun, secara umum pariwisata masal diartikan sebagai kegiatan pariwisata yang memiliki banyak komponen dan menghadirkan wisatawan dalam jumlah besar yang secara otomatis akan mendatangkan dampak dan keuntungan yang besar pula (Siswantoro, Anggoro, dan Sasongko, 2012). 
Sedangkan pariwisata alternatif merupakan bentuk pariwisata yang berorientasi kepada kelestarian lingkungan dan budaya. Berbeda dengan wisata massal yang menghadirkan wisatawan dalam jumlah besar, wisata alternatif secara kuantitas hanya menghadirkan sekumpulan kecil wisatawan. Meskipun demikian, wisata alternatif menawarkan kedalaman makna dan pengalaman lebih mendalam terhadap objek wisata yang dikunjungi. Dilihat dalam perkembangannya, pariwisata alternatif mengalami beberapa jenis wisata dengan fokus kepada potensi sumber daya alam yang ada di lokasi wisata, setidaknya pariwisata alternatif dapat dibagi menjadi beberapa jenis seperti green tourism, geotoursm, responsible toursm dan sustainable tourism (Theng, 2015). Dari berbagai jenis pariwisata tersebut, hakekatnya memiliki kesamaan, yaitu: Pertama, kelestarian lingkungan menjadi fokus utama. Kedua, adanya pelibatan masyarakat lokal dalam pengembangannya. Ketiga, adanya proses mencari pengetahuan dan pemahaman mengenai alam dan masyarakat. Keempat, menawarkan kesan dan makna yang lebih mendalam terhadap objek wisata yang dikunjungi.

Lebih lanjut Garrod (2001) menyatakan bahwa terdapat dua pendekatan terkait dengan prinsip perencanaan yang dikaitkan dengan pariwisata, yaitu: Pertama, merupakan pendekatan yang cenderung formal yang menekankan kepada keuntungan potensial dari ekowisata. Kedua, merupakan pendekatan yang disamakan dengan perencanaan partisipatif dimana adanya upaya untuk menyeimbangkan antara pembangunan dengan perencanaan terkendali. Salah satu bentuk dari pembangunan pariwisata secara partisipatif yaitu Community Based Tourism (CBT) atau diterjemahkan sebagai pariwisata berbasis komunitas/masyarakat, bentuk pariwisata ini memberikan peluang kepada masyarakat setempat untuk turut serta dalam pengembangan pariwisata.

Hal tersebut di atas sejalan dengan pendapat Hausler (dalam Sunaryo, 2013) yang menyatakan bahwa CBT merupakan pendekatan pembangunan pariwisata 
yang menekankan kepada masyarakat lokal, baik itu yang terlibat secara langsung maupun tidak terlibat secara langsung. Lebih lanjut Suansri (2003) mendefinisikan CBT sebagai pariwisata yang memperhitungkan aspek-aspek keberlanjutan lingkungan, sosial dan budaya.

Pemahaman mengenai pariwisata berbasis komunitas/masyarakat seperti yang dijelaskan ahli di atas, maka dapat dikatakan masyarakat dalam proses pengembangan kebijakan wisata ditempatkan dalam dua posisi sekaligus; Pertama sebagai objek yang memiliki hak untuk turut menentukan pengembangan pariwisata yang akan dilaksanakan. Kedua, sebagai subjek yang harus mendapat manfaat dan keuntungan dalam pengembangan pariwisata. Hal tersebut sejalan dengan pemahaman Sunaryo (2013) yang menyatakan bahwa terdapat tiga prinsip dalam pengembangan pariwisata berbasis masyarakat, yaitu: Pertama, melibatkan masyarakat dalam pengambilan keputusan. Kedua, terdapat kepastian masyarakat lokal menerima manfaat. Ketiga, pemberihan edukasi tentang pariwisata kepada masyarakat lokal.

\section{Metode Penelitian}

Penelitian ini merupakan penelitian kualitatif dengan menggunakan pendekatan kepustakaan (library research), sebagaimana diungkapkan oleh Zed (2004) yang menyatakan bahwa studi kepustkaaan merupakan penelitian yang memanfaatkan sumber kepustakaan untuk memperoleh data penelitian, sehingga dalam penelitian ini referensi kepustakaan menjadi sumber utama. Studi kepustakaan dalam penelitian ini dilakukan dengan cara mencari dan mempelajari berbagai literatur, karangan ilmiah, baik berupa buku-buku, jurnal dan dokumen lainnya yang berhubungan dengan pengembangan desa wisata.

Sumber data dalam penelitian ini berupa buku, jurnal, laman web dan referensi lainnya yang dianggap relevan dengan tema dalam penelitian ini, yaitu 
mengkaji pengembangan desa wisata berbasis masyarakat. Analisis data dalam penelitian ini dilakukan melalui metode analisis deskriptif, dimana diartikan sebagai usaha untuk mengumpulkan dan menyusun suatu data, kemudian dilakukan suatu analisis terhadap data tersebut, adapun data-data yang dikumpulkan berupa katakata, gambar dan bukan dalam bentuk angka-angka (Surakhmad, 1990). Dalam hal ini data-data mengenai pengembangan desa wisata dikumpulkan dari berbagai sumber untuk kemudian oleh peneliti dilakukan analisis dan interpretasi dari data tersebut.

\section{Hasil Penelitian}

\section{Desa Dalam Konteks Pengembangan Partisipatif}

Desa wisata merupakan kawasan perdesaan yang menawarkan keseluruhan suasana yang mencerminkan keaslian perdesaan baik dari kehidupan sosial ekonomi, sosial budaya, adat istiadat, keseharian dan lain sebagainya yang mampu dikembangkan sebagai objek pariwisata (Hadiwijoyo dalam Fitari dan Ma`arif, 2017). Sejalan dengan pemahaman tersebut, Muliawan (dalam Atmoko, 2014) mengatakan bahwa desa wisata memiliki potensi keunikan dan daya tarik wisata yang khas yang dikelola dan dikemas secara menarik dan alami dengan pengembangan fasilitas pendukung wisatanya.

Dikaitkan dengan desa sebagai daerah pengembangan wisata, maka pengembangan desa wisata dapat diartikan sebagai proses menjadikan desa sebagai objek wisata, dimana desa meliputi sumber daya alam, masyarakat, budaya dan segala potensi yang ada di dalamnya yang berkaitan satu dengan yang lainnya. Sehingga, pengembangan desa wisata secara partisipatif menjadi mutlak untuk dilakukan, mengingat elemen yang ada di desa banyak dan kesemuanya itu saling terkait satu dengan yang lainnya. Adapun alasan lain mengapa desa wisata perlu dikembangkan dengan pendekatan partisipatif, yaitu: 
Pertama, masyarakat merupakan sasaran utama dari pembangunan desa, sehingga segala aktivitas yang terdapat didalamnya harus diorientasikan dan ditujukan kepada peningkatan kesejahteraan masyarakat. Kedua, masyarakat merupakan bagian integral dari desa itu sendiri, sehingga tidak memungkinkan adanya kebijakan pembangunan desa, termasuk di dalamnya pengembangan pariwisata tanpa adanya pelibatan masyarakat. Ketiga, masyarakat memiliki kepemilikan sejarah desa, sehingga masyarakat jauh lebih mengetahui kelemahan dan potensi yang dimiliki desa dibanding dengan pihak luar, sehingga dalam proses pengembangan desa wisata kontribusi pengalaman dan pengetahuan masyarakat dalam pengembangan pariwisata sangat dibutuhkan. Dari pemahaman tersebut di atas, dapat dikatakan bahwa masyarakat menjadi sentral dalam pengembangan pariwisata berbasis masyarakat, keberhasilan dari pengembangan desa wisata berbasis masyarakat terletak kepada sejauhmana masyarakat terlibat dan berkontribusi dalam proses pengembangan wisata yang akan dan telah dilaksanakan.

\section{Desa dalam Konteks Pengembangan Pariwisata}

Suatu desa dalam prosesnya untuk dikembangkan menjadi desa wisata memerlukan dukungan dari berbagai pihak, baik pemerintah desa, masyarakat maupun pihak swasta yang dalam hal ini penanam modal harus bersinergi satu sama lain. Ketiga pihak harus memiliki persamaan preferensi mengenai pengembangan potensi yang dimiliki oleh desa yang bersangkutan beserta dengan segala implikasinya apabila dikembangkan menjadi desa wisata.

Pemerintah desa sebagai pihak yang diberikan kewenangan dalam penyelenggaraan pembangunan tingkat desa tidak hanya harus mampu mensinergikan berbagai kebijakan pembangunan dengan pengembangan wisata yang ada, tetapi juga harus mampu mengakomodasi pengembangan desa wisata 
tersebut sebagai sarana untuk meningkatkan perekonomian masyarakat dan mendorong percepatan pembangunan desa.

Masyarakat desa harus mampu membuka diri terhadap pihak luar atau wisatawan, serta mampu mengembangkan diri dengan potensi yang dimilikinya, sehingga pengembangan pariwisata sepenuhnya dapat didorong dengan kapasitas kelembagaan masyarakat yang baik dan pengembangan desa wisata dapat dimanfaatkan oleh masyarakat sebagai sarana peningkatan ekonomi dan kualitas hidup.

Sedangkan pemilik modal harus mampu mengakomodasi tuntutan masyarakat dan menempatkan masyarakat sebagai potensi yang mampu mendorong akselerasi pengembangan pariwisata, selain itu pemilik modal harus mampu meyakinkan bahwa pengembangan pariwisata sejalan dengan program pembangunan yang dilakukan oleh pemerintah desa. Dengan adanya sinergi dari ketiga aktor kepentingan tersebut, maka pengembangan desa wisata akan berjalan sesuai dengan keinginan dan tujuan bersama, serta memberikan keuntungan kepada para pihak yang terlibat di dalamnya.

Proses transisi suatu desa menjadi desa wisata pada prakteknya tidak terjadi secara begitu saja, melainkan didasarkan kepada beberapa alasan yang mendasarinya. Beberapa alasan yang mendorong pengembangan desa wisata, yaitu: Pertama, bagian dari pelestarian nilai tradisi/ budaya. Kedua, bagian dari pengembangan potensi baik itu sumber daya alam, nilai budaya maupun sumber daya manusiawi. Ketiga, kebijakan untuk membuka lapangan pekerjaan. Keempat, mendorong akselerasi pembangunan desa. Kelima, adanya dorongan eksternal, seperti tingginya minat masyarakat untuk melihat keunikan objek wisata yang ada di desa yang bersangkutan. Setelah terjadinya proses pengembangan desa menjadi desa wisata, maka dapat memberikan banyak perubahan kepada desa tersebut dan 
menjadikan pembeda antara desa wisata dengan desa lainnya, adapun perbedaannya dapat dirinci dalam tabel 1.

Tabel 1. Perbedaan Desa Non-Wisata dengan Desa Wisata

\begin{tabular}{|c|c|c|}
\hline Aspek & Desa Non-Wisata & Desa Wisata \\
\hline Potensi & $\begin{array}{l}\text { Tidak memiliki kekhasan yang } \\
\text { menonjol baik budaya, adat } \\
\text { istiadat, karakteristik } \\
\text { masyarakat, maupun belum } \\
\text { dioptimalkannya potensi desa } \\
\text { yang ada yang akan menarik } \\
\text { minat wisatawan. }\end{array}$ & $\begin{array}{l}\text { Memiliki kekhasan yang } \\
\text { menjadi daya tarik wisatawan } \\
\text { baik itu berupa potensi } \\
\text { keindahan alam, adat istiadat } \\
\text { maupun karakteristik dari } \\
\text { masyarakatnya. }\end{array}$ \\
\hline $\begin{array}{l}\text { Karakter } \\
\text { Masyarakat }\end{array}$ & $\begin{array}{l}\text { Tertutup kepada warga } \\
\text { pendatang/wisatawan. }\end{array}$ & $\begin{array}{l}\text { Terbuka kepada warga } \\
\text { pendatang/wisatawan. }\end{array}$ \\
\hline $\begin{array}{l}\text { Persepsi } \\
\text { Masyarakat } \\
\text { Terhadap } \\
\text { Pariwisata }\end{array}$ & $\begin{array}{l}\text { Memandang dan } \text { besikap } \\
\text { bahwa pariwisata bukan } \\
\text { sebagai sektor yang mampu } \\
\text { meningkatkan perekonomian } \\
\text { masyarakat dan mampu } \\
\text { meningkatkan pembangunan } \\
\text { desa. }\end{array}$ & $\begin{array}{l}\text { Mendukung dan mendorong } \\
\text { kegiatan pariwisata yang } \\
\text { mampuratkan } \\
\text { perekonomian masyarakat dan } \\
\text { mampuraningkatkan } \\
\text { pembangunan desa. }\end{array}$ \\
\hline $\begin{array}{l}\text { Mata } \\
\text { Pencaharian }\end{array}$ & $\begin{array}{l}\text { Homogen/Bergantung kepada } \\
\text { pengelolaan sumber daya alam, } \\
\text { seperti pertanian, perkebunan } \\
\text { dan sebagainya. }\end{array}$ & $\begin{array}{l}\text { Heterogen, tidak hanya kepada } \\
\text { pengelolaan sumber daya alam, } \\
\text { tetapi juga kepada mata } \\
\text { pencaharian lainnya, seperti } \\
\text { sektor jasa (contoh: } \\
\text { penginapan, transportasi/travel } \\
\text { wisata.). }\end{array}$ \\
\hline $\begin{array}{l}\text { Orientasi } \\
\text { Pembangunan } \\
\text { Desa }\end{array}$ & $\begin{array}{l}\text { Pariwisata bukan menjadi } \\
\text { bagian rencana pembangunan } \\
\text { desa, sehingga program } \\
\text { pembangunan yang ada tidak } \\
\text { ditujukan untuk mendukung } \\
\text { kegiatan pengembangan } \\
\text { pariwisata. }\end{array}$ & $\begin{array}{l}\text { Pariwisata sebagai bagian dari } \\
\text { rencana pembangunan desa, } \\
\text { sehingga } \\
\text { pembangunan program } \\
\text { infrastruktur ditunjukan untuk } \\
\text { mendukung pengembangan } \\
\text { pariwisata. }\end{array}$ \\
\hline
\end{tabular}

Sumber: Analisis Penulis, 2019. 
Didasarkan kepada tabel 1, dapat diketahui bahwa pengembangan desa wisata tidak hanya merubah mata pencaharian masyarakat yang bergeser kepada sektor jasa, tetapi juga telah merubah struktur masyarakat desa. Masyarakat desa yang selama ini memiliki karakter tertutup terhadap pihak luar (Effendi, 2013; Julaikha dan Bahri, 2014; Rafika, 2016), dituntut untuk bersifat terbuka dan melakukan kerjasama demi mendorong terlaksananya pengembangan desa wisata. Di sisi lain, pengembangan desa wisata juga telah merubah arah pembangunan desa yang tadinya kepada pengelolaan sumber daya alam seperti pertanian dan perkebunan, berubah menjadi pembangunan desa berbasis jasa wisata.

Perubahan tersebut merupakan sesuatu yang wajar dimana tidak hanya adanya interaksi individu dengan latar belakang yang berbeda yang akan melahirkan perubahan sosial, tetapi juga adanya perubahan arah kebijakan pembangunan, ekonomi dan dinamika politik pada akhirnya akan turut menentukan perubahan sosial di desa, hal ini sebagaimana diungkap oleh Buwaiti (2000) yang menyatakan bahwa perubahan itu dapat melibatkan semua faktor seperti faktor sosial, ekonomi, politik dan budaya.

\section{Tipologi Desa Wisata}

Berbagai pakar telah mengemukakan berbagai tipologi desa yang didasarkan kepada perspektif keilmuannya masing-masing, seperti tipologi desa berdasarkan pertumbuhan ekonomi, tipologi desa berdasarkan mata pencaharian masyarakat, tipologi desa berdasarkan lingkungan atau juga tipologi desa berdasarkan kedekatan ruang wilayah dengan perkotaan.

Desa wisata merupakan tipologi tersendiri dimana desa dibagi ke dalam karakter-karakter berdasarkan potensi dan pola pengembangan pariwisata. Berdasarkan kepada desa wisata yang ada di Indonesia, maka setidaknya tipologi desa wisata dapat diklasifikasikan ke dalam tiga bentuk, yaitu: Pertama, desa wisata 
adat atau budaya dimana dasar potensi dan pengembangan pariwisata berupa budaya atau adat istiadat. Bentuk adat atau budaya yang dikembangkan bisa berupa sistem kepercayaan (religi), sistem kesenian, sistem sosial, arsitektur tradisional maupun lainnya yang memiliki hubungan dengan budaya dan adat istiadat.

Kedua, desa wisata alam/konservasi alam, dimana dasar potensi dan pengembangan pariwisata berupa keindahan alam seperti alam pegunungan, air terjun dan lain sebagainya. Konservasi alam merunut kepada Undang-Undang No. 5 Tahun 1990 tentang Konservasi Sumberdaya Alam Hayati dan Ekosistemnya (Indonesia, 1990) dimana kawasan konservasi dibagi ke dalam dua jenis, yaitu Kawasan Suaka Alam dan Kawasan Pelestarian Alam, maka pengembangan dengan klasifikasi konservasi alam didasarkan kepada kedua jenis lingkungan konservasi tersebut.

Ketiga, desa wisata ekonomi kreatif, dimana dasar potensi dan pengembangan pariwisata berupa pengembangan ekonomi berbasis kreatifitas masyarakat lokal. Masyarakat memproduksi berbagai produk yang menjadi minat wisatawan seperti kerajinan tangan dengan ciri atau khas lokal desa yang bersangkutan. Prakteknya klasifikasi desa wisata tidak hanya memberikan perbedaan dari potensi dan pengembangan pariwisata saja, tetapi juga memiliki berbagai perbedaan antara satu dengan yang lainnya dalam banyak aspek seperti yang bisa dijelaskan dalam tabel 2. 
Tabel. 2. Perbedaan Klasifikasi Desa Wisata

\begin{tabular}{|c|c|c|c|}
\hline Aspek & $\begin{array}{l}\text { Desa Wisata } \\
\text { Adat/Budaya }\end{array}$ & $\begin{array}{l}\text { Desa Wisata Alam/ } \\
\text { Konservasi Alam }\end{array}$ & $\begin{array}{c}\text { Desa Wisata } \\
\text { Ekonomi Kreatif }\end{array}$ \\
\hline Daya tarik & $\begin{array}{l}\text { Nilai adat istiadat, } \\
\text { budaya, atau tradisi } \\
\text { masyarakat. }\end{array}$ & $\begin{array}{l}\text { Keindahan alam } \\
\text { atau lingkungan. }\end{array}$ & \begin{tabular}{ll}
\multicolumn{2}{l}{ Pruduk-produk } \\
kerajinan/ $\quad$ produk \\
ekonomi & kreatif \\
masyarakat. &
\end{tabular} \\
\hline $\begin{array}{l}\text { Tujuan } \\
\text { pengembangan } \\
\text { wisata }\end{array}$ & $\begin{array}{lr}\begin{array}{l}\text { Pelestarian } \\
\text { istiadat, }\end{array} & \begin{array}{r}\text { adat } \\
\text { atau }\end{array} \\
\text { masyarakat. } & \text { tradisi }\end{array}$ & $\begin{array}{l}\text { Konservasi alam } \\
\text { atau lingkungan. }\end{array}$ & $\begin{array}{l}\text { Pengembangan } \\
\text { ekonomi } \\
\text { masyarakat. }\end{array}$ \\
\hline Sumbe & $\begin{array}{l}\text { Berada menyatu } \\
\text { dengan lingkungan } \\
\text { masyarakat. }\end{array}$ & $\begin{array}{lr}\text { Berada } & \text { menyatu } \\
\text { atau } & \text { terpisah } \\
\text { dengan lingkungan } \\
\text { masyarakat. }\end{array}$ & $\begin{array}{lr}\text { Berada } & \text { menyatu } \\
\text { atau } & \text { terpisah } \\
\text { dengan lingkungan } & \\
\text { masyarakat. }\end{array}$ \\
\hline $\begin{array}{l}\text { Tujuan } \\
\text { wisatawan }\end{array}$ & $\begin{array}{l}\text { Mengetahui dan } \\
\text { memahami adat } \\
\text { istiadat, budaya, } \\
\text { atau tradisi } \\
\text { masyarakat. }\end{array}$ & $\begin{array}{l}\text { Menikmati } \\
\text { keindahan alam } \\
\text { atau lingkungan. }\end{array}$ & 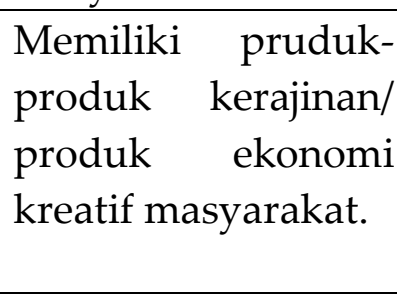 \\
\hline $\begin{array}{l}\text { Proses interaksi } \\
\text { dengan } \\
\text { masyarakat } \\
\text { lokal atau } \\
\text { masyarakat } \\
\text { setempat }\end{array}$ & $\begin{array}{lr}\text { Interaksi } & \\
\text { masyarakat } & \text { lokal } \\
\text { menjadi } & \text { bagian } \\
\text { integral } & \text { dalam } \\
\text { wisata. } & \end{array}$ & $\begin{array}{lr}\text { Interaksi } & \\
\text { masyarakat } & \text { lokal } \\
\text { menjadi } & \text { bagian } \\
\text { eksternal } & \text { dalam } \\
\text { wisata. } & \end{array}$ & $\begin{array}{lr}\text { Interaksi } & \\
\text { masyarakat } & \text { lokal } \\
\text { bisa menjadi bagian } & \text { ba } \\
\text { internal } & \text { atau } \\
\text { eksternal dalam } & \text { wisata. }\end{array}$ \\
\hline
\end{tabular}

Sumber: Analisis Penulis, 2019.

Berdasarkan kepada tabel 2, pada dasarnya adanya karakter yang berbedabeda antara satu desa wisata dengan desa wisata lainnya tidak hanya mampu mengembangkan desa berdasarkan kepada potensi dan karakternya masing-masing, tetapi juga dapat memberikan diversifikasi objek wisata bagi wisatawan, sehingga terdapat berbagai alternatif objek wisata yang bisa menjadi pilihan sesuai dengan minatnya masing-masing. Klasifikasi desa wisata dalam prakteknya juga tidak memiliki batas secara tegas, dalam artian terdapat beberapa desa wisata yang menggabungkan potensi yang ada semisal desa wisata alam dimana masyarakatnya turut membuat kerajinan sebagai cendera mata khas desanya. Meskipun demikian, 
akan ada potensi utama yang dikembangkan sebagai daya tarik pariwisata dan menjadi ciri khas dari desa yang bersangkutan.

\section{Peran Masyarakat dalam Pengembangan Desa Wisata Berbasis Masyarakat}

Peran menurut Wulansari (2009) diartikan sebagai konsep tentang apa yang harus dilakukan oleh individu dalam masyarakat, sejalan dengan pengertian tersebut Paul dan Chester (1993) mengartikan peran sebagai perilaku yang diharapkan dari seseorang yang memiliki status. Dari pemahaman tersebut, peran hakekatnya merupakan tindakan seseorang yang dilakukan dikaitkan dengan kedudukannya dalam suatu struktur sosial.

Dikaitkan dengan masyarakat, maka peran masyarakat memiliki artian tindakan yang dilakukan oleh sekelompok orang yang mencerminkan kesamaan perilaku sebagai sebuah entitas komunal yang berkaitan dengan struktur sosial tertentu. Dari pemahaman tersebut di atas, maka peran masyarakat memiliki sifat-sifat sebagai berikut:

a. Perilaku sekelompok orang, dimana tindakan tersebut dilakukan secara bersama-sama oleh individu-individu yang ada dalam suatu kelompok.

b. Adanya pembagian peran masing-masing anggota kelompok.

c. Adanya kesamaan perilaku dari kelompok tersebut yang meliputi pola pikir dan pola tindak.

d. Perilaku tersebut merupakan perwujudan dari ciri atau kehendak kelompok.

e. Dilakukan dalam suatu struktur sosial tertentu.

Pemahaman peran masyarakat tersebut dalam konteks pengembangan desa wisata memiliki artian sebagai adanya kesamaan pola pikir maupun pola tindak dari masyarakat perdesaan mengenai potensi wisata yang ada di desanya, untuk kemudian masyarakat tersebut secara bersama-sama melakukan suatu tindakan dalam upayanya untuk mewujudkan tujuan pengembangan pariwisata sebagai 
sebuah dimensi yang mampu memberikan dampak positif bagi mereka, serta mampu mencerminkan identitas mereka sebagai sebuah kesatuan masyarakat yang memiliki struktur sosial yang khas atau unik.

Lebih lanjut mengenai bentuk peran masyarakat dalam pengembangan pariwisata, setidaknya dapat dibagi ke dalam 3 (tiga), yaitu: Pertama, peran masyarakat sebagai pemrakarsa yang mana masyarakat menjadi pihak pertama yang menemukenali dan menggali potensi pariwisata. Kedua, peran masyarakat sebagai pelaksana yang mana masyarakat menjadi pihak yang menginisiasi pelaksanaan dan pengembangan pariwisata sampai dengan terwujudnya objek wisata.

Ketiga, peran masyarakat sebagai penyerta yang mana masyarakat turut serta dalam proses pengembangan pariwisata, namun bukan sebagai pihak yang memiliki kewenangan dalam pengembangan pariwisata, melainkan turut berpartisipasi sebagai salah satu aktor atau pelaku pengembangan wisata. Keempat, peran masyarakat sebagai peninjau yang mana masyarakat bukan pihak yang mengembangkan pariwisata, namun melakukan pengawasan mengenai proses maupun dampak dari adanya pengembangan pariwisata. Kelima, masyarakat berperan sebagai penerima manfaat yang mana masyarakat tidak terlibat dalam pengembangan pariwisata, namun menerima manfaat dari adanya pengembangan pariwisata. Berbagai peran masyarakat tersebut pada hakekatnya ditujukan untuk mendukung pengembangan pariwisata, namun dengan intensitas dan kepentingan yang berbeda-beda, adapun perbedaannya lebih lanjut dapat dijelaskan dalam tabel 3. 
Tabel 3. Uraian Peran Masyarakat dalam Pengembangan Pariwisata.

\begin{tabular}{|c|c|c|c|}
\hline $\begin{array}{c}\text { Peran } \\
\text { Masyarakat }\end{array}$ & Kontribusi & $\begin{array}{c}\text { Tindakan } \\
\text { Masyarakat }\end{array}$ & $\begin{array}{c}\text { Tujuan Keterlibatan } \\
\text { Masyarakat }\end{array}$ \\
\hline $\begin{array}{l}\text { Sebagai } \\
\text { Pemrakarsa }\end{array}$ & $\begin{array}{l}\text { Memberikan } \\
\text { kontribusi baik } \\
\text { sumbangan } \\
\text { pemikiran, tenaga, } \\
\text { dana hingga yang } \\
\text { lainnya. }\end{array}$ & $\begin{array}{l}\text { Terlibat aktif dalam } \\
\text { pengembangan } \\
\text { potensi wisata untuk } \\
\text { dijadikan objek } \\
\text { wisata. }\end{array}$ & $\begin{array}{lr}\text { Menggali } & \text { potensi } \\
\text { pariwisata } & \text { yang ada } \\
\text { dan } & \text { menerima } \\
\text { manfaat } & \text { dari } \\
\text { pengembangan } & \\
\text { pariwisata. } & \end{array}$ \\
\hline $\begin{array}{l}\text { Sebagai } \\
\text { Pelaksana }\end{array}$ & $\begin{array}{l}\text { Memberikan } \\
\text { kontribusi penuh } \\
\text { baik sumbangan } \\
\text { pemikiran, tenaga, } \\
\text { dana hingga yang } \\
\text { lainnya. }\end{array}$ & $\begin{array}{l}\text { Terlibat aktif dalam } \\
\text { pelaksanaan } \\
\text { pengembangan } \\
\text { pariwisata. }\end{array}$ & $\begin{array}{l}\text { Mengembangkan } \\
\text { potensi pariwisata } \\
\text { yang ada dan } \\
\text { menerima manfaat } \\
\text { dari pengembangan } \\
\text { pariwisata. }\end{array}$ \\
\hline $\begin{array}{l}\text { Sebagai } \\
\text { Penyerta }\end{array}$ & $\begin{array}{lr}\text { Memberikan } & \\
\text { kontribusi } & \text { secara } \\
\text { terbatas } & \text { yang } \\
\text { didasarkan } & \text { kepada } \\
\text { peran yang diberikan. }\end{array}$ & $\begin{array}{l}\text { Terlibat aktif dalam } \\
\text { pelaksanaan } \\
\text { pengembangan } \\
\text { pariwisata. }\end{array}$ & $\begin{array}{l}\text { Mengembangkan } \\
\text { potensi pariwisata } \\
\text { yang ada dan } \\
\text { menerima manfaat } \\
\text { dari pengembangan } \\
\text { pariwisata. }\end{array}$ \\
\hline $\begin{array}{l}\text { Sebagai } \\
\text { Pemantau }\end{array}$ & $\begin{array}{l}\text { Memberikan } \\
\text { kontribusi secara } \\
\text { terbatas } \quad \text { berupa } \\
\text { kegiatan } \\
\text { pemantauan. }\end{array}$ & $\begin{array}{l}\text { Mendorong } \\
\text { terlaksananya } \\
\text { pengembangan } \\
\text { pariwisata dengan } \\
\text { tidak terlibat } \\
\text { langsung. }\end{array}$ & $\begin{array}{l}\text { Mengetahui dampak } \\
\text { pengembangan } \\
\text { pariwisata. }\end{array}$ \\
\hline $\begin{array}{l}\text { Sebagai } \\
\text { Penerima } \\
\text { Manfaat }\end{array}$ & $\begin{array}{l}\text { Tidak memberikan } \\
\text { kontribusi dalam } \\
\text { pengembangan } \\
\text { wisata. }\end{array}$ & $\begin{array}{l}\text { Mendukung } \\
\text { pengembangan } \\
\text { pariwisata. }\end{array}$ & $\begin{array}{l}\text { Hanya menerima } \\
\text { manfaat dari } \\
\text { pengembangan } \\
\text { pariwisata. }\end{array}$ \\
\hline
\end{tabular}

Sumber: Analisis Penulis, 2019.

Berdasarkan pada tabel 3, adanya perbedaan peran masyarakat yang disesuaikan dengan kapasitas masing-masing dalam praktek tidak dimaksudkan sebagai batasan yang tegas dimana peran yang dijalankan hanya bersifat tunggal, melainkan peran tersebut bersifat dinamis dan dimungkinkan bersifat jamak. Semisal, masyarakat berperan sekaligus baik sebagai pemrakarsa dan sebagai pelaksana dari pengembangan pariwisata, maka kontribusi dalam pngembangan 
parisiwata menjadi satu kesatuan. Batasan yang dibuat dimaksudkan hanya untuk mempertegas kontribusi didasarkan kepada kapasitasnya, bukan untuk memberikan disparitas kontribusi diantara peran yang ada tersebut.

\section{Proses Keterlibatan Masyarakat dalam Pengembangan Desa Wisata Berbasis Masyarakat}

Masyarakat harus dilibatkan dalam pengembangan desa wisata sejak dari awal, masyarakat dijadikan aktor utama mulai dari tahap identifikasi masalah hingga tahap penyelenggaraan desa wisata. Keterlibatan masyarakat sejak dari awal tersebut didasarkan kepada beberapa hal, yaitu: Pertama, masyarakat merupakan bagian integral dari desa, sehingga berbagai bentuk kebijakan pembangunan yang ada di desa harus diketahui masyarakat sejak dari awal. Kedua, secara kultural, masyarakat memiliki partisipasi yang aktif dalam pembangunan, sehingga adanya pengembangan desa wisata dengan melibatkan masyarakat sejak dari awal akan mendorong percepatan dan keberhasilan penyelenggaraan desa wisata. Ketiga, masyarakat memiliki hak untuk menerima manfaat dari pengembangan desa wisata sejak dari awal proses identifikasi masalah. Keterlibatan masyarakat dalam pengembangan desa wisata tersebut dapat dijelaskan dalam gambar 1. 


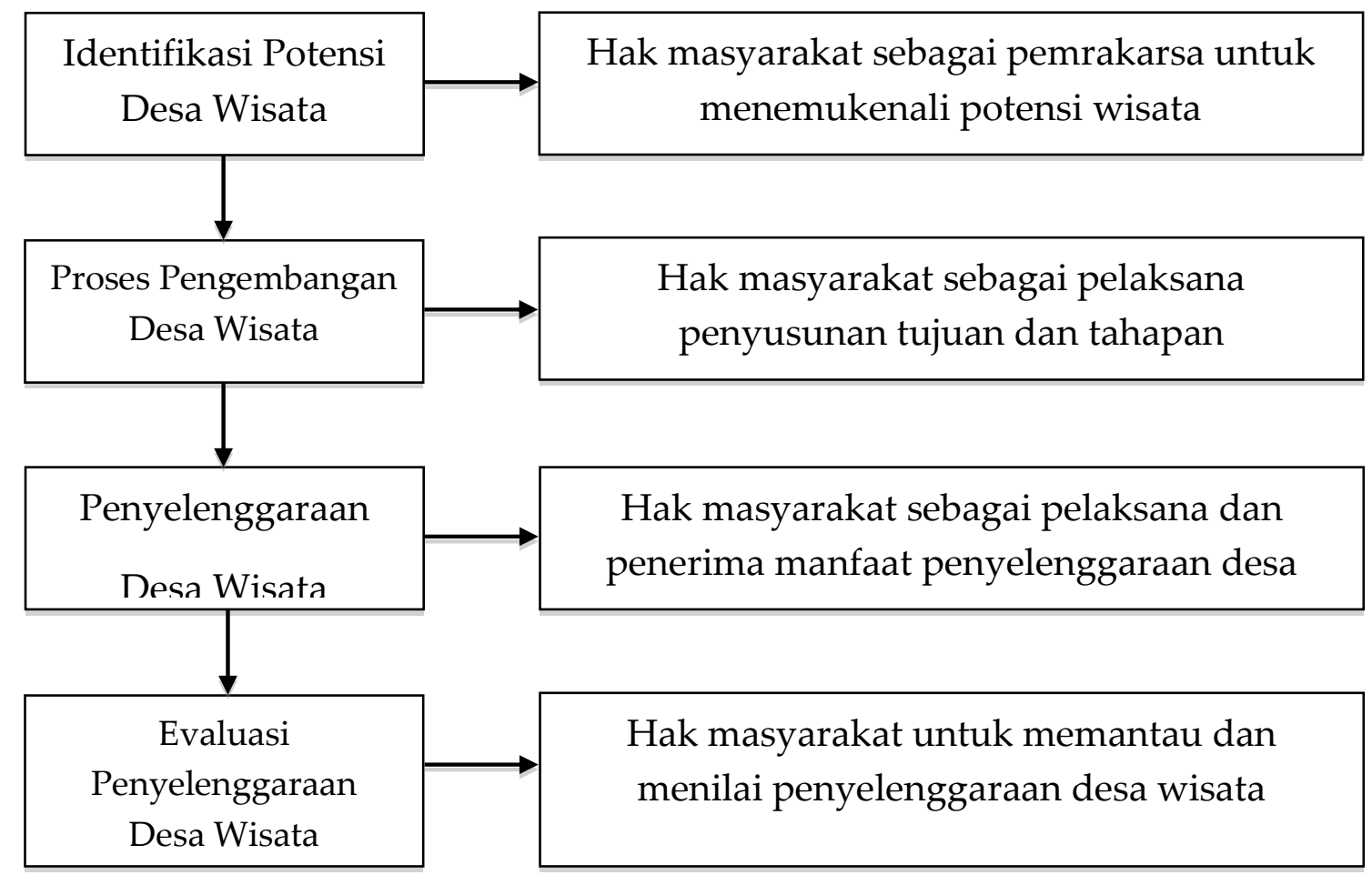

Gambar 1. Proses Keterlibatan Masyarakat (Sumber: Analisis Penulis, 2019)

Proses identifikasi pengembangan desa wisata merupakan penggalian secara benar mengenai hal-hal yang dianggap mampu dikembangkan menjadi daya tarik wisata. Dalam proses ini, masyarakat dilibatkan langsung untuk mengenali sendiri potensi yang ada di desanya, hal ini menjadi penting dikarenakan masyarakat merupakan pemilik dari potensi yang ada di desa, sehingga penggalian yang dilakukan oleh masyarakat sendiri akan mampu melahirkan kajian yang utuh mengenai potensi yang sebenarnya ada dan bisa dikembangkan sesuai dengan pemahaman, kebutuhan, kemampuan dan kebutuhan masyarakat. Manfaat penggalian potensi oleh masyarakat akan memberikan pengetahuan sejak awal bagi masyarakat mengenai potensi yang dimiliki desa, sehingga masyarakat memiliki gambaran mengenai seperti apa bentuk pengembangan potensi tersebut hingga menjadi daya tarik dalam pengembangan desa wisata.

Proses pengembangan desa wisata merupakan tahapan dimana potensi desa wisata direncanakan untuk dikembangkan menjadi objek wisata. Dalam proses ini, 
masyarakat dilibatkan sebagai pihak yang memiliki hak menyusun perencanaan pengembangan desa wisata, seperti penetapan tujuan, penyusunan program dan rencana kegiatan sampai dengan penetapan rencana anggaran. Keterlibatan masyarakat secara langsung dalam proses pengembangan desa wisata menjadi penting, hal ini didasarkan kepada alasan sebagai berikut:

Pertama, mengakomodasi keinginan dan tuntutan masyarakat, pengembangan desa wisata harus didasarkan atas adanya keinginan masyarakat untuk mengembangkan potensi yang ada di desanya sebagai sarana untuk meningkatkan kesejahteraan masyarakat, sehingga keterlibatan msyarakat ditujukan untuk memastikan bahwa pengembangan desa wisata sesuai dengan keinginan dan tuntutan masyarakat. Kedua, membangun partisipasi masyarakat dalam proses pengembangan desa dimana keterlibatan masyarakat ditujukan untuk menggugah rasa kepemilikan masyarakat terhadap potensi desa wisata yang dikembangkan sehingga masyarakat memiliki kehendak untuk terlibat dan memiliki rasa memiliki terhadap pengembangan desa wisata. Ketiga, sarana bagi masyarakat untuk menumbuhkan dan memperkuat kelembagaan masyarakat yang ada, hal ini dikarenakan keterlibatan masyarakat secara bersama-sama alam mengembangkan desa wisata akan meningkatkan pemahaman dan kemampuan masyarakat dalam pengembangan potensi yang dimilikinya, sehingga pada akhirnya akan menciptakan kelembagaan masyarakat yang kuat.

Penyelenggaraan desa wisata merupakan proses untuk mewujudkan tujuan pengembangan desa wisata, dalam proses ini masyarakat dilibatkan baik sebagai penyelenggara maupun sebagai penerima manfaat. Peran masyarakat sebagai penyelenggara merupakan hak masyarakat untuk mengelola desa wisata, keberlangsungan dan keberlanjutan desa wisata menjadi hak masyarakat, sedangkan peran masyarakat sebagai penerima manfaat ditujukan untuk peningkatan kesejahteraan masyarakat, hal ini menjadi penting dikarenakan 
masyarakat harus menjadi pihak pertama yang diuntungkan dalam pengembangan desa wisata.

Proses evaluasi terhadap penyelenggaraan desa wisata menjadi penting untuk menilai apakah tujuan yang telah ditetapkan sudah bisa dicapai atau belum, masyarakat memiliki hak untuk menilai keberhasilan tersebut dikarenakan dari proses awal masyarakat sudah dilibatkan sehingga dalam proses penilaian terhadap penyelenggaraan desa wisata, masyarakat jauh lebih mengetahui dibanding dengan pihak lainnya. Selain itu, evaluasi terhadap penyelenggaraan desa wisata yang dilakukan oleh masyarakat akan meningkatkan kapasitas masyarakat seta menciptakan akuntabilitas dalam keseluruhan proses penyelenggaraan desa wisata.

Dari pemahaman tersebut di atas, maka pengembangan desa wisata yang melibatkan masyarakat sejak dari awal sampai dengan akhir merupakan jawaban akan adanya tuntutan untuk menghadirkan masyarakat sebagai pemilik potensi desa wisata yang berhak mengelola dan menerima manfaat dari pengembangan desa wisata, sehingga keberadaan desa wisata mampu menumbuhkan rasa kepemilikan, memperkuat kelembagaan sampai dengan meningkatkan kesejahteraan masyarakat.

\section{Penutup}

Pengembangan desa wisata merupakan bentuk kebijakan pembangunan perdesaan yang mencoba melakukan diversifikasi desa yang selama ini banyak berbasis kepada pertanian. Desa wisata dikembangkan untuk menjadi desa yang berbasis kepada industri wisata, baik usaha jasa maupun usaha niaga dalam bentuk produk wisata. Desa wisata dalam pengembangannya merupakan proses penggalian potensi yang ada di desa baik itu berasal dari unsur alam, sosial, budaya, masyarakat atau lainnya, sehingga sifat alamiah dan kelestarian karakteristik desa tetap terjaga dan terpelihara. 
Masyarakat sebagai subjek dan objek pembangunan desa harus senantiasi dilibatkan dalam keseluruhan proses pengembangan desa wisata, mengingat bahwa tujuan pengembangan desa wisata selain untuk mengembangkan karakteristik, nilai-nilai tradisi dan budaya menjadi sebuah objek wisata, juga untuk meningkatkan kesejahteraan masyarakat, sehingga masyarakat harus berperan dan menjadi pihak yang diuntungkan.

Pengembangan desa wisata berbasis masyarakat merupakan pendekatan yang menawarkan peran yang lebih kepada masyarakat untuk terlibat dalam keseluruhan proses pengembangan desa wisata. Pengembangan desa wisata berbasis masyarakat juga mengakui eksistensi masyarakat sebagai bagian integral dari desa, sehingga proses yang dilaksanakan ditujukan sepenuhnya untuk memberdayakan masyarakat dan memberikan keuntungan yang sebesar-besarnya kepada masyarakat.

\section{Daftar Pustaka}

Atmoko, T. P. H., 2014. Strategi Pengembangan Potensi Desa Wisata Brajan Kabupaten Sleman. Jurnal Media Wisata, 12(2), 146-154.

Buwaiti, Y., 2000. Dampak Sosial Budaya dari Perkembangan Pariwisata di Jambi (Studi Kasus Jasa Hiburan Umum di Kecamatan Pasar Kotamadya di Jambi). Universitas Indonesia.

Dewi, M. H. U., Fandeli, C., dan Baiquni, M., 2013. Pengembangan Desa Wisata Berbasis Partisipasi Masyarakat Lokal Di Desa Wisata Jatiluwih Tabanan Bali. Jurnal Kawistara, 3(2), 129-139.

Effendi, T. N., 2013. Budaya Gotong-Royong Masyarakat dalam Perubahan Sosial Saat Ini. Jurnal Pemikiran Sosiologi, 2(1), 1-18.

Fitari, Y., dan Ma`arif, S., 2017. Manfaat Pengembangan Desa Wisata Wonolopo terhadap Kondisi Sosial, Ekonomi dan Lingkungan Masyarakat Lokal. Jurnal Wilayah Dan Lingkungan, 5(1), 29-44.

Garrod, B., 2001. Local Partisipation in the Planning and Management of Eco-tourism. Bristol: University of the West of England.

Indonesia. Undang-Undang No. 5 Tahun 1990 tentang Konservasi Sumberdaya Alam Hayati dan Ekosistemnya (1990). Indonesia. 
Julaikha, S., dan Bahri, S., 2014. Nilai-Nilai Gotong-Royong Dalam Masyarakat Petani Padi Sawah Di Desa Sungai Siput Kecamatan Siak Kecil Kabupaten Bengkalis. Jurnal Jom FISIP, 1(2), 1-13.

Karyono, H., 1997. Kepariwisataan. Jakarta: PT. Remaja Rosda Karya.

Lindberg, K., Enriquez, J., dan Sproule, K., 1997. Ecotourism questioned: Case studies from Belize. Annals of Tourism Research, 23(3), 543-562.

Muallisin, I., 2007. Model Pengembangan Pariwisata Berbasis Masyarakat Di Kota Yogyakarta. Jurnal Penelitian Bappeda Kota Yogyakarta, 2(1), 5-14.

Nawawi, A., 2013. Partisipasi Masyarakat Dalam Pengelolaan Wisata Pantai Depok Di Desa Kretek Parangtritis. Jurnal Nasional Pariwisata, 5(2), 103-109.

Neil, J., dan Wearing, S., 1999. Ecotourism: Impacts, Potentials and Possibilities. Oxford: Reed Educational and Professional Publishing Ltd.

Paul, B. H., dan Chester, L. H., 1993. Sosiologi. Jakarta: Erlangga.

Purnamasari, A. M, 2011. Pengembangan Masyarakat Untuk Pariwisata Di Kampung Wisata Toddabojo Provinsi Sulawesi Selatan. Jurnal Perencanaan Wilayah Dan Kota, 22(1), 49-64.

Rafika, C., 2016. Lemahnya Kontrol Sosial Pada Masyarakat Pedesaan (Studi Kasus Anak-Anak dan Remaja Kecanduan Menghisap Lem Aibon di Desa Suka Negeri, Kecamatan Topos Kabupaten Lebong). Fokus Jurnal Kajian Keislaman Dan Kemasyarakatan, 1(1), 33-46.

Rizkianto, N., dan Topowijono., 2018. Penerapan Konsep Community Based Tourism Dalam Pengelolaan Daya Tarik Wisata Berkelanjutan (Studi Pada Desa Wisata Bangun, Kecamatan Munjungan, Kabupaten Trenggalek). Jurnal Administrasi Bisnis (JAB), 58(2), 20-26.

Siswantoro, H., Anggoro, S., dan Sasongko, D. P., 2012. Strategi Optimasi Wisata Massal Di Kawasan Konservasi Taman Wisata Alam Grojogan Sewu. Jurnal Ilmu Lingkungan, 10(2), 100-110.

Spillane, J. J., 1987. Pariwisata Di Indonesia Sejarah dan Prospeknya. Yogyakarta: Kanisius.

Suansri, P., 2003. Community Based Tourism Handbook. Thailand: REST Project.

Sukirman, O., 2017. Apakah Anggaran Pemasaran Pariwisata Pemerintah Efektif dalam Meningkatkan Jumlah Kunjungan Wisatawan? (Studi Kasus di Indonesia Tahun 2011-2016). Tourism and Hospitality Essentials (THE) Journal, $7(2), 121-128$.

Sunaryo, B., 2013. Kebijakan Pembangunan Destinasi Pariwisata Konsep dan Aplikasinya di Indonesia. Yogyakarta: Gava Media.

Surakhmad, W., 1990. Pengantar Penelitian Ilmiah. Bandung: Tarsito. 
Suwantoro, G., 2001. Dasar-Dasar Pariwisata. Yogyakarta: Andi.

Theng, S., 2015. Mass Tourism vs Alternative Tourism? Challenges and New Positionings. Retrieved February 21, 2019, from https://journals.openedition.org/ etudescaribeennes/7708\#authors

Trianggono, A., Wiloso, P. G., dan Sasongko, G., 2018. Pariwisata Dalam Perspektif Actor Network Theory (Studi Kasus Top Selfie Pinusan Kragilan Desa Pogalan, Jawa Tengah, Indonesia). Jurnal Pariwisata Pesona, 3(2), 91-104.

Wahab, S., 2003. Manajemen Kepariwisataan. Jakarta: Pradnya Paranita.

Wulansari, D., 2009. Sosiologi Konsep dan Teori. Bandung: Refika Aditama.

Zed, M., 2004. Metode Penelitian Kepustakaan. Jakarta: Yayasan Obor Indonesia.

\section{Profil Penulis}

Dr. Dian Herdiana, S.IP., M.AP ialah alumnus Program Studi Doktor Ilmu Pemerintahan Universitas Padjadjaran, saat ini menjadi dosen di Sekolah Tinggi Ilmu Administrasi (STIA) Cimahi. Artikel ini merupakan hasil tulisan pada saat menempuh program studi doktoral. Minat studi adalah bidang pengembangan masyarakat dan pembangunan partisipatif perdesaan. Email: kyberdian@gmail.com. 